\title{
Research on Enterprise Management in the Era of Knowledge Economy
}

\author{
Fang Yuan \\ Qingdao Huanghai University, Qingdao, Shandong, 266427
}

\begin{abstract}
The 21 st century is the era of knowledge economy, knowledge-based economy is knowledge-based economy, is based on modern science and technology as the core, based on knowledge and information production, storage, use and consumption of the economy. In the era of knowledge economy, knowledge resources have replaced material resources and financial resources become the most important and strategic resources. Economic growth is more dependent on the development and effective use of knowledge, rather than the expansion of physical assets. With the rise of knowledge economy in the global scope, the management and management environment of enterprises is changing greatly. The knowledge economy is leading to the profound change of enterprise management. It calls for the new management concept, Way of birth.
\end{abstract}

Keywords: Enterprise Management, Knowledge Economy, Research Method

\section{Introduction}

Since the 1990s, human society has begun to enter the era of knowledge-based economy, with high-tech industry as the mainstay and intellectual resources as the mainstay. In this new economic era, knowledge has become a key factor in economic development and internal motivation. In the face of the hasty advent of the knowledge economy, the original management model appears to be inadequate, and sometimes even become obstacles to the development of social productive forces. Modern enterprises in the market competition, not only in customer satisfaction to meet the needs of the competitive strategy and marketing strategy, but also reflected in the pioneering spirit, rapid response, creating 
customers, beyond the competitor's ability to innovate. Therefore, under the background of knowledge economy, it is imperative for enterprises to innovate to gain competitive advantage as the entity of economic growth and adapt to the requirements of knowledge economy in management.

In the coordination between man and nature, the goal of sustainable development, industrial technology invented the guiding ideology has changed. The guiding ideology of traditional industrial technology invention is single, as much as possible the use of natural resources in order to obtain the maximum profit, without considering or rarely consider the environmental benefits, ecological and social benefits; built in the inexhaustible natural resources, the environment Capacity inexhaustible basis, or even to the natural plunder for the purpose, it can not be said that the separation of technology and science tragedy. The era of high technology to produce a variety of natural resources is almost depleted, the growing crisis of the times, and science and technology integration, reflecting the human nature and human social science comprehensive understanding. Therefore, the guiding ideology of high-tech is the scientific, rational, comprehensive and efficient use of existing resources, while the development of unused natural resources to replace depleted natural resources. Such as information science and technology software, life science and technology of genetic engineering on the consumption of resources and traditional technology is quite different.

The traditional industrial economy requires a lot of capital, equipment, tangible assets play a decisive role, while the knowledge economy is the knowledge, intelligence, intangible assets play a decisive role. Of course, the knowledge economy also requires capital investment, high-tech industry and even venture capital investment, but if there is no more information, knowledge, intellectual input, it is not high-tech industry. At present, the intangible assets of many hightech enterprises in the United States have exceeded $60 \%$ of the total assets. The appreciation of intangible assets will also bring about changes in social values, with more knowledge of people to get high-paid work increased, the output of knowledge power increased.

\section{The Current Situation and Problems of Chinese Enterprise Management}

The concept of enterprise management behind, not keep up with the requirements of the development of the situation. According to the Fifth Plenary Session of the 14th CPC Central Committee, from the "Ninth Five-Year" period to 2010, China to form a relatively complete socialist market economic system of the goal, we must first from the ideological concept from the traditional plan Economic system to the socialist market economic system changes, and enterprises as the mainstay of the market economy should first be in the enterprise management concept to achieve this change. However, the current situation of Chinese enterprises is not satisfactory, many of the business management concept 
seriously lagging behind the requirements of market economy, market awareness, risk awareness, legal awareness, capital management awareness, innovation, brand awareness and merchandise Protection of consciousness are very weak, corporate managers are accustomed to the planned economy under the conditions of enterprise management methods, re-leadership performance, light economic efficiency; re-extensive operation, light-intensive management; heavy asset management, light capital operation; , Light the market; heavy external environment, light internal management; heavy bonus benefits, light staff education; heavy business reputation, light brand strategy; heavy immediate interests, light and long-term development, etc., in the ideological and market economy with a serious departure from the requirements. If this situation does not change in time, it is bound to the survival and development of Chinese enterprises have a very negative impact.

At present, China has made great progress from the planned economic system to the market economic system. However, from the present situation of enterprise management, it has not completed the transition to a market economy. In a sense, most enterprises are still Stay in the planned economy under the traditional enterprise management level. In recent years, the products produced by enterprises is not the right way, the production and marketing rate decreased, the phenomenon of serious inventory backlog obviously reflects a considerable number of enterprises will still be the production management as the focus of enterprise management, product research and development, marketing But not enough attention. To adapt to the market economy of enterprise management, should be all from the market, starting from the meet consumer demand, on the one hand to strengthen the enterprise's new product research and development links, to launch to meet consumer demand, guide the market consumption of the new Products, on the other hand, it is necessary to strengthen product sales links, expand marketing network, to achieve a new enterprise product development, production and sales of a virtuous circle. From the current point of view, the middle strong, two weak, it is difficult for many enterprises in China has always been difficult to adapt to the market economy, one of the important reasons.

In economic work, business management is the eternal theme. However, in recent years the reform, a considerable number of business-to-business management has not given due attention. Some enterprises do not have timely amendments to the internal rules and regulations formulated by the planned economy system, most of these rules and regulations have not meet the requirements of market economy development, enterprise management in a state of no rules; some enterprises in the process of institutional adjustment Free to merge the quality, measurement and other functions, so that some of the key internal infrastructure in a blank state; many enterprises lax management, labor discipline lax, on-site management confusion; some companies even from the date of its creation, Always did not do a good job of basic management of enterprises, labor-free assessment, the quality of non-test, no material consumption, production without strict management procedures, without a variety of basic records, ledger form. Part of the enterprise product quality is not strict, raw materials, outsourcing parts do not acceptance, not inspection, resulting in 
product quality decline. In addition, there are many companies ignore the staff training and education, resulting in decline in the quality of workers, it is difficult to adapt to modern enterprise socialization of production requirements.

\section{The Way of Enterprise Management Innovation}

Management concept of innovation in the entire innovation system plays a very important role, but also involves all aspects of enterprise management, the center is always around the people to start. Therefore, enterprises should adhere to the "people-oriented" concept, establish a good new concept of management. After understanding the connotation of management innovation, we can apply the service-oriented management philosophy, learning-based management concept, the concept of team-based management approach to enterprise management innovation, so that better design and positioning of employees within the company Development prospects, and effectively coordinate the work between employees, so that enterprises become learning organizations, to strengthen their own strength, but also through effective team to achieve deeper and more flexible with the enterprise to run efficiently.

Enterprise management First, profit impulse, the second is the market pressure. Enterprises in order to pursue more profits and adapt to market demand for management innovation carried out the results should also be the same as with technological innovation, to obtain the necessary incentives. The face of outstanding contributions to the management personnel, should also be rewards. Based on the complexity and difficulty of management innovation, the motivation for managers should not be simply expressed as material benefits. Management innovation behavior is a strong sense of professionalism and a sense of achievement as a driving force. We find that many managers are motivated not only to pay for money, but to have a strong sense of accomplishment. Therefore, the management and scientific and technical personnel treated the same, so that the management and technology sector by the business leaders of the same importance for them to create a good working environment and conditions, from the social honor and material aspects of their business to stimulate a good business height Sense of mission and sense of responsibility, are important elements of management innovation mechanism.

Plan is the decision-making activities required to complete the implementation of the task time and space on the co-ordination arrangements in business management innovation should consider two new changes: First, in the development of plans to consider factors to increase production capacity in addition to enterprises, The scale of production and market research, the results of the forecast, but also pay special attention to technological development and changes in the external environment. Because technology development more and more attention by enterprises, technology itself is difficult to measure with quantitative indicators. The external environment is also complex, new opportunities and challenges come at any time, the degree of opportunity and risk is difficult to quantify and measure the calculation; the second is the plan to 
implement the process to have the ability to respond. In order to cope with sudden changes, it is necessary to make the plan flexible. To this end, new aids such as decision support system and expert system should be added to make the plan more precise.

Decision-making is the management center, from the development trend of enterprise management, decision-making functions should be further updated. Non-managers also have their own wisdom and experience, so that their decisionmaking can mobilize their enthusiasm and enthusiasm to improve decisionmaking science; the second is from the internal staff decision-making update to absorb the participation of external decision-making. Outside the enterprise customers, the public and consulting experts from the perspective of a more objective view of the problem, help enterprises to form the right decision-making; third decision-making should focus on rational analysis and intuitive perception combined. The current business environment is more volatile, managers need to use experience to determine the trend of development.

Cost management is an important system of enterprise management. Under the knowledge-based economy, there are many new features of cost management. The proportion of product cost will change radically. The dematerialization of material production will greatly change the product cost. . Cost management to further expand the content, management will shift the focus of research and development, after-sales service costs and staff training costs. Environmental management costs will also be incorporated into the vision of business management. And the formation of cost competitive advantage will become the core of cost management. To this end, the introduction of activity-based costing and activity-based cost management to improve the intangible assets (such as the status of staff education, work capacity, operational capacity, etc.) and the formation of products with significant relations intangible assets (such as technology, patents, etc.) Product Cost. The costs of natural resource consumption, environmental pollution costs and the resulting social environmental costs should be calculated.

\section{Conclusion}

On the basis of summing up the advanced management theories and management practices in the world and combining with the present situation and existing problems of Chinese enterprises management, this paper puts forward some opinions on the management innovation of Chinese enterprises: To cultivate knowledge workers to improve the quality of management innovation, to foster management innovation environment through information management and team management, at the same time, the implementation of appropriate incentive mechanism. Management and technology are the two wheels of enterprise development. Chinese enterprises can improve their management level, meet the challenge of knowledge economy and promote the healthy, stable and sustainable development of the enterprise only on the basis of learning advanced 
management theory and combining with their actual implementation of management innovation. .

\section{References}

[1] Chai Junzhi, Zhou Daquan. The WTO framework, the competitive intelligence work of China's enterprises to rethink. Modern Information, 3(6), pp. 27-29, 2000.

[2] the domestic enterprise knowledge management research summary. Sun Lili. Jin Tu Journal, 6(4), pp. 33-36, 2003.

[3] The relationship between competitive intelligence and knowledge management. Qin Tiehui, Shu Wenfang, Yan Chuangye. Library and Information Service, 11(5), pp. 65-69, 2011.

[4] Huang Pinqi, Hou Suli, Li Guangquan. The Theory of Enterprise Strategy in the Era of Knowledge Economy. Frontiers of Theory, 3(1), pp. 32-33, 2003.

[5] on the knowledge economy era of enterprise knowledge management . Wangcheng. Shandong Electric Power College, 4(3), pp. 67-69, 2010. 